\title{
Brief historical review of Parkinson's disease at 200 years of its description
}

\author{
Kenia Arredondo-Blanco, ${ }^{1}$ Rosalía Zerón-Martínez, ${ }^{1}$ Mayela Rodríguez-Violante ${ }^{1}$ and \\ Amin Cervantes-Arriaga ${ }^{2}$ \\ ${ }^{1}$ Clinic of Movement Disorders; ${ }^{2}$ Clinical Laboratory for Neurodegenerative Diseases, Secretaría de Salud, Instituto Nacional de Neurología and \\ Neurocirugía, Ciudad de México, Mexico
}

\begin{abstract}
The original description of what currently is known as Parkinson's disease was published 200 years ago. During both these centuries, knowledge on symptomatology, pathophysiology, genetics and pharmaceutical and surgical treatment has significantly increased; however, this nosological entity continues to be of imprecise origin and progressive evolution. In the present review, the historical events that contributed to describe and improve the understanding of this disease are summarized.
\end{abstract}

KEY WORDS: Parkinson's disease. Parkinsonism. History of medicine.

\section{Introduction}

Very few disease eponyms have prevailed throughout history; however, the skill of James Parkinson to carefully narrate the semiology, clinical characteristics, to approach the cause of the problem and to maintain the humbleness to recognize that he was not the first one to describe it made him deserving of such honor, whereby he transcended throughout time.

The present review is originated in the opportunity to commemorate two centuries of Parkinson's disease (PD) first published description as a clearly defined nosological entity. Herein, the relevant moments that helped the description and understanding of the disease throughout history are presented.

\section{History of motor phenomenology}

"Essay on the shaking palsy", by James Parkinson, published in 1817, has been regarded as the masterful description of the disease that bears his name. ${ }^{1}$ However, at present we understand that this disease is older than initially believed; apparently, ancestral cultures had knowledge about it; ${ }^{2}$ even Parkinson himself recognized that other authors who preceded him had already described signs of the disease. ${ }^{3}$

One of the oldest pieces of information is found in Egyptian papyri corresponding to the $19^{\text {th }}$ Dynasty (1500-1200 BC), where the sialorrhea of patients with this disease is evoked by describing a king to whom "age had loosened his mouth" and "spitted continuously". ${ }^{4}$

The Ayurveda (āyuh: 'duration of life', veda 'knowledge'), or old traditional medicine system of India, was published around $1000 \mathrm{BC}$ and the kampavata (kampa: tremor), a disease that is characterized by scarce movement, excess of saliva, drowsiness and "reptilian gaze", is therein mentioned. ${ }^{5}$ The Chinese Traditional Medicine Treatise (Nei-Jing), which dates back to around $800 \mathrm{BC}$, is also known to describe people with head and hands tremor, the explanation of which was similarly attributed to age. ${ }^{4}$

In the Bible Old Testament there are some interesting quotes; an example of it is found in Ecclesiastes 12:3, which says: "One day the keepers of the house will tremble, and mighty men will stoop; the grinding ones will cease because they are few, and those who look through the windows will grow dim", describing
Gac Med Mex. 2018;154:617-623

Contents available at PubMed www.gacetamedicademexico.com 
the posture and tremor that could make reference to PD. Many years later, Galen of Pergamum, considered to be one of the most influential doctors in Europe, defined the tremor and could distinguish between that of action and that of rest in his observations. ${ }^{5}$

Unfortunately, the information relative to PD disappeared for centuries, perhaps due to the many territorial battles Europe was submerged in, which reduced the life expectancy of the population of those times, and it could therefore be suspected that the age of death prevented senescence from being a common aspect within the society and probably some neurodegenerative diseases may therefore have not been that common. ${ }^{6}$

Subsequent descriptions that seem to be related to PD emerge again from the $17^{\text {th }}$ century on: in 1641 , the famous doctor Nicolaes Tulp picked up the term tremor. This character was so important in his time, that he deserved one of the most widely known portraits in history, painted by Dutch painter Rembrandt. Similarly, Silvio de La Boe spoke about the characteristics of action and rest tremor, a description whereby he was mentioned by Parkinson in his essay. ${ }^{7}$

Other figures, such as Leonardo Da Vinci, Shakespeare or Rembrandt and doctors as important as Johannes Baptiste Sagar, Boissier de Sauvages, John Hunter and Chomel also made reference to tremor and other motor disorders in their works. In 1758, Gaubius referred having observed "a man who was able to run, but not to walk", whereby he alluded to the gait abnormalities observed in this pathology. ${ }^{5}$ Finally, in 1817 was James Parkinson's essay published, where details of the disease, extracted from the observation of six patients, were specifically collected for first time. At that moment, tremor, bradykinesia and postural instability were announced to be the most important signs of this entity. Parkinson indicated that it was "involuntary shaking... in parts that are not in activity"; in addition, he underscored "the propensity to flex the trunk forward". ${ }^{3}$

By describing the natural history of the disease, with a clearly coherent and simple wording, he revealed that the disease onset was slowly progressive, that it started unilaterally and that in short time it compromised the contralateral side of the body, with subsequent compromise of the erect position when walking and development of antepulsion of gait. He mentioned that, as time advanced, the patient felt that movements lost precision and performed them with great difficulty. Falls became more notorious owing to the inability to easily lift the legs and the language became unintelligible, and thus the patient required the permanent presence of a caregiver.

Perhaps one of its considerations with more significance at present was the description of some non-motor symptoms of the disease as, for example, sleep disturbances, constipation, sialorrhea and sphincter alterations.

James Parkinson found numerous detractors, although, finally, direct observations from famous doctors of the time turned out to be useful to refine diagnostic data, as it occurred with Jean-Martin Charcot, who was not able to obtain a version of the referred "Essay on the shaking palsy" translated into French until 1881, thanks to the translation task he himself entrusted to his students, after which he issued the following comment:

This is a descriptive and vivid definition that is correct in many cases, most of them in fact, and will always have the advantage over others of having been the first one, but it is wrong by being too general.

Charcot is the one who first associated rigidity with the disease and pointed out that it is its cardinal sign, managing to differentiate it from spasticity. ${ }^{8}$ This way, it appeared that the knowledge to describe the disease had been reached, but centuries would have to elapse to show that other manifestations, currently referred to as non-motor symptoms, belong to the same entity.

\section{History of PD anatomy and histopathology}

After James Parkinson's clinical description in 1817, as well as Jean Martin Charcot's writings entitled "Leçon sur le maladies du systeme nerveux", one of the most important events for the understanding of $P D$ was the discovery of neuronal loss in the pars compacta of the substania nigra. This loss was identified as the pathological lesion that characterizes PD, which is maintained up to this day. ${ }^{9}$

At the beginning of the $20^{\text {th }}$ century, the pathogenic mechanisms of the disease began to be systematicalIy investigated. In 1913, the pathologist Friederich Lewy described the alpha-synuclein cytoplasmic inclusions located in neurons of the dorsal motor nucleus of the vagus nerve and of the nucleus basalis of Meynert. These inclusions later received the denomination of Lewy bodies. ${ }^{10}$ Six years later, in 1919, Konstantine Trétiakoff gave substantia nigra its name, described in detail its location and associated the loss of neurons in this area as part of PD's findings."1 
In 1960, with the use of electron microscopy, Lewy's bodies' filamentous internal structure was demonstrated, ${ }^{12}$ and it is until 2003 when Braak et al. published the results of serial studies they performed on post mortem brains, where the presence of Lewy's bodies in different areas of the nervous system was demonstrated, with a model to stage the progression of the disease and its relationship with motor and non-motor symptoms also being designed. ${ }^{13}$

In the 1980s, neurotoxic effects were recognized in a group of addicts to a "new synthetic heroin". These subjects secondarily developed a Parkinsonism related to lesion in the substantia nigra. This is how MPTP (1-methyl-4-phenyl-1,2,3,6 tetrahydropyridine) was identified as the causative agent; subsequently, this finding gave origin to experimental models of PD in animals, which up to this day continue to be of great utility. ${ }^{14}$

At present, not only the presence of alpha-synuclein deposits has been described, but also of tau protein and beta amyloid, which has led to the use of the term proteinopathies, where probably the predominant pathology is that which phenotypically distinguishes PD from other diseases such as taupathies, Alzheimer's disease or frontotemporal dementia. ${ }^{13}$

In the last decade, a cell-to-cell transmission of $\alpha$-synuclein has been documented, at least in animal and cell-based models, which has led to consider the possibility for PD being a similar disorder to prion diseases. ${ }^{15}$ If proven, this concept will not only be of great relevance for the understanding of the pathophysiology of the disease, but will also offer the opportunity to develop molecular therapeutics to modify disease progression. ${ }^{16}$

\section{History of Parkinson's disease genetics}

For decades, PD was considered to be a pathology of exclusively sporadic occurrence, since even when there was evidence of a familiar component, there were no scientific techniques available that would allow verifying such phenomenon. However, technological evolution allowed for this paradigm to change.

The first genetic investigations on this pathology started in the late 1990s, where it was assumed that at least some percentage of patients with PD have a genetic cause despite a monozygotic discordance in twins that was shown by studies of those days. In 1997, when studying four large families with PE, a mutation in the gene that encodes $\alpha$-synuclein was discovered to cause a dominant form of PD inheritance,$^{17}$ and a relationship could be established between $\alpha$-synuclein accumulations and Lewy bodies..$^{18}$ As a consequence, in the following years this protein became the target of numerous research studies.

Juvenile Parkinsonism also benefited from the genetic material study techniques. In 1998, mutations in the now called parkina protein were discovered to be the cause of a form of early presentation of the disease..$^{19}$ In 2003, mutations in the DJ1 gene could be identify and this was associated as a cause of early-onset parkinsonism..$^{20}$ PINK 1 was discovered in 2004, and it was suggested to be the second most common cause of autosomal recessive parkinsonism. ${ }^{21}$ On that same year, LRRK2 was recognized by high-resolution recombination mapping and sequencing of candidate genes in 46 families, whereby long research studies were initiated. ${ }^{22}$

Growth in genetic knowledge has allowed understanding PD pathophysiology and phenomenology, in addition to generating interest in strategies such as gene therapy and cellular reprogramming for the future management of the disease. To date, there are 17 different known genes considered to be causative, either in an autosomal dominant or recessive form; in addition, a large number of genes has been identified, which, in spite of not being causative, are considered of risk.

\section{History of the treatment of PD}

There are descriptions in the literature dating almost 3000 years back, from Ayurvedic medicine. The classical Indian medical treatise refers the Kampavata disease, which was treated with a combination of vegetable remedies deriving from plants of the genus mucuna (Mucuna pruriens), with high levodopa contents obtained by grinding the seeds. Mucuna is a liana of the Asian and American rainforests, and it was therefore also used in the Amazon region. In Ayurvedic medicine, sick persons were given a concoction of mucuna seeds dust cooked in cow's milk, which improved tremor, bradykinesia, stiffness and the cramps, although presence of sialorrhea was observed. Recently, each dose of seed powder has been shown to contain around $200 \mathrm{mg}$ of levodopa. ${ }^{23}$

In writings of ancient herbal medicine, information is found on treatments against tremor with Datura stramonium seeds owing to its anticholinergic effect. Broad beans and other exotic legumes contain levodopa as well and have been used for several centuries 
in the treatment of PD. ${ }^{24,25}$ On the other hand, Wilhelm Erb introduced the therapeutic use of scopolamine since 1887, and similar preparations were used in the 1950s owing to their pharmacological anticholinergic effects.

Ordestein, who was Charcot's intern, mentioned the use of belladonna alkaloids for tremor control in his medical thesis. ${ }^{26}$ Charcot's treatments with anticholinergic effects provided the pharmacological bases of modern antiparkinsonian drugs. The historical opportunity to analyze the primary treatments of the disease was found with the discovery of letters in the personal library of this eminent neurologist. These letters cover a of 15 -month period, from January 1863 to March $1864 .^{27}$

William Gowers, a Charcot contemporary, used similar therapeutic strategies. Additionally, Gowers described the negative effect of stress and physical and mental fatigue, recommending a quiet life; ${ }^{28}$ for tremor he indicated hyoscyamine, arsenic and hemp, as well as the combination of Cannabis with opium. ${ }^{29}$

In 1910, in a London laboratory, dopamine was synthesized for the first time by researchers George Barger and James Ewens. In the same laboratory, Henry Dale gave dopamine its name. It should be mentioned that levodopa, dopamine precursor was chemically synthesized by Casimir Funk in $1911 .{ }^{30}$

Between 1950 and 1960, Arvid Carlsson, winner of the Nobel Prize in Physiology and Medicine in 2000, would change the course of PD treatment with his woks in relation to dopamine. When investigating the vascular changes generated by reserpine in rabbits, he observed that the adverse effect by it generated was akinesia. After hard research works, he managed to reverse this effect with the use of D, L DOPA (L-3,4 dihydroxyphenylalanine. ${ }^{31}$ Subsequently, dopamine depletion in the striatum was described to be responsible for the presence of a reserpine-mediated akinetic effect. Austrian Oleh Hornykiewicz, winner of the Wolf medicine prize in 1979, was responsible for this remarkable description. ${ }^{32,33}$ Hornykiewicz was the first one to propose the use of levodopa for the treatment of the disease. ${ }^{34}$

One of the most significant experiments carried out on levodopa pharmacology was in charge of Kathleen Montagu, with animal studies. In November 1957, she discovered intracellular dopamine and its distribution in the brain; in addition, she also noticed that levodopa increases catecholamine levels in the brain. Similarly, in 1958 Montagu described that reserpine elicits dopamine depletion and that levodopa restores its levels. ${ }^{35}$ In that same period, Hermann Blaschko, in the Physiology Laboratory of the University of Cambridge, proposed that levodopa and dopamine are intermediate metabolites in the biosynthesis of catecholamines. ${ }^{36}$ In those days, Peter Holtz discovered the dopamine enzyme decarboxylase and documented that levodopa is synthesized into dopamine through this enzyme. ${ }^{37}$ In 1967, George Cotzias demonstrated the efficacy and safety of the use of levodopa in people with PD, at doses of 4 and $8 \mathrm{~g}$ per day; as a consequence of this trial, levodopa was introduced in the treatment of PD together with the addition of dopamine decarboxylase inhibitors, which is currently one of the most widely used drugs and with higher benefit in motor symptoms. ${ }^{38}$

The inclusion of levodopa adequate doses was an innovative achievement in the management of symptoms of the disease. ${ }^{39}$ However, shortly after, it became evident that its prolonged use causes motor complications, ${ }^{40}$ which forced to look for other different alternatives for pharmacological treatment. ${ }^{41}$

On the other hand, Kendal B. Corbin demonstrated in 1949 that trihexyphenidyl, an anticholinergic, is useful in the control of PD motor symptoms, ${ }^{42}$ prolonging the use of these medications. An important advance in the field of pharmacological treatment was the development of dopamine agonists, monoamine oxidase $B$ enzyme inhibitors and catechol-o-methyltransferase inhibitors. These drugs were initially approved for human use in the decades of 1970 and 1980.

Apomorphine was the first dopamine agonist to be synthesized in the $19^{\text {th }}$ century; however, it dates from the era of the Mayans, who in religious rituals used an extract from the root and trunk of an aquatic plant (Nymphaea ampla and Nymphaea caerulea) with aphrodisiac and hallucinogenic properties, and which would later be discovered to contain apomorphine. ${ }^{43,44}$ In 1869, Matthienssen and Wrigth observed that when dehydrating morphine with hydrochloric acid, a substance was obtained, which they called apomorphine; in those days, its therapeutic use began, initially as antiemetic. ${ }^{45,46}$ In 1884 it was proposed for the treatment of patients with parkinsonism, ${ }^{47}$ but it was not until 1951 that Schwab et al. reported that apomorphine dramatically, but in temporarily, improved the symptoms presented by patients with PD. ${ }^{48}$ Subsequently, in 1965, Ernst pointed out the structural similarity between apomorphine and dopamine..$^{49}$

In 1970, Cotzias et al. reevaluated the use of apomorphine and reported antiparkinsonian effectiveness; 
however, toxicity and the need for parenteral administration limited its utility. ${ }^{50}$ Later, the use of apomorphine was tried by oral route,,$^{51}$ but this practice was given up due to the presence of hyperazoemia in long-term therapies. In the middle of the 1980s, Andrew Lees and Gerald Stern showed that subcutaneous administration using an infusion pump improved the off period by $50 \%$ in patients with PD.52

Administration route technical difficulties and adverse effects limited the use of apomorphine, but in turn this promoted the use of other dopaminergic agonists. Initially, ergotamine-derived dopaminergic agonists were used (pergolide, bromocriptine, cabergolide, lisuride), which fell into disuse due to their adverse effects (nausea, drowsiness, hallucinations); prolonged use is related to higher risk of pleural, pericardial, retroperitoneal fibrosis and fibrosis of the heart valve. ${ }^{53-55}$ It was then when PD treatment was focused on the use of non-ergotamine dopamine agonists, such as pramipexole and ropirinole..$^{56}$ Although their symptomatic effect is lower than that of levodo$\mathrm{pa}$, their main indication arose from the need to reduce the risk of motor complications at late stages of the disease; associated problems have been reason enough to create pharmacological options that generate continuous dopaminergic stimulation, which decreases pulsatility in dopaminergic stimulation levels. Rotigotine, a daily transdermal application dopamine agonist, began to be used in this $21^{\text {st }}$ century..$^{57,58} \mathrm{Sim}$ ilarly, both ropinirole and pramipexole prolonged-release presentations were developed. ${ }^{59}$ Currently, apomorphine subcutaneous infusion is considered an advanced treatment for patients with complicated disease. ${ }^{60}$

In the early 2010's, disease-associated symptoms, the non-motor symptoms, were described, with multiple treatments for their control and this way improve patients' quality of life. The search for new alternatives and improvement of existing options still continues.

Another therapeutic strategy involved the use of inhibitors of specific enzymes implicated in dopamine metabolism, such as monoamine oxidase $B$ (MAO-B). Inhibition of this enzyme increases the concentration of endogenous dopamine and secondarily reduces PD symptoms. The first MAO-B inhibitor used in PD was selegiline (initially known as deprenil) and, more recently, rasagiline. ${ }^{61}$ Another relevant medication is amantadine, approved in 1976 as an antiviral, but its use for PD was based on an accidental discovery as antiparkinsonian agent. Schwab noticed an unexpected benefit in the severity of tremor, gait and bradykinesia in patients with PD and in patients with post-encephalitic parkinsonism. ${ }^{62}$ Currently, the development of new therapies with neuroprotective effect is focused on monoclonal antibodies.

\section{Surgical therapy in Parkinson's disease}

In 1908, the surgeon Victor Alexander Haden Horsley and engineer Robert Henry Clarke, in London, England, were the pioneers in creating stereotaxic equipment, ${ }^{63}$ which was to be a breakthrough in PD surgery. After 1930, but prior to World War II, advances in neurosurgery were focused on performing lesions on corticospinal pathways at different levels in order to try to correct tremor; however, the sequelae were catastrophic. Meyer described the effects that occur with lesions to the caudate, globus pallidus and the lenticular nucleus, demonstrating that PD-secondary tremor and rigidity improve with these surgical procedures; however, mortality and morbidity were high. ${ }^{64}$ At the same time, Bucy, Case, and Klemme focused on ablative surgery, whereby the cerebral cortex was lesioned for the treatment of parkinsonian tremor; the sequel of this type of surgery was hemiparesis, which is why it was abandoned. ${ }^{65,66}$

Around 1939-1940, with the presence of military conflicts at the international level, science had an intricate road. Hostilities between countries ended in 1945 , but it was until 1947 that neurosurgical techniques were approved and stereotactic interventions began to be used in humans to perform procedures involving lesions, mainly in the thalamus and the globus pallidus. ${ }^{67}$

Early in the decade of 1950 , Cooper, during a surgical procedure on a Parkinsonian patient, accidentally cut the anterior choroidal artery, so he was forced to ligate it to prevent the formation of a hematoma; however, this procedure caused an unexpected control of tremor and rigidity on the contralateral side of the generated injury. ${ }^{68}$ Thalamotomy was the most widely used surgery in the decade from 1950 to 1960 , a technique used by Cooper in the United States and Hassler in Germany, since the ventrolateral thalamus was the ideal place for the control of motor symptoms. ${ }^{69}$ Subsequently, between 1960 and 1970, with the introduction of levodopa, there was a marked reduction in the use of stereotaxy for surgical purposes focused on PD.

In the mid-1980s, the neurosurgical techniques were reborn. Lauri Laitinen et al. recognized the 
limitations of pharmacological treatments and retook ablative procedures, particularly posteroventral pallidotomy. ${ }^{70}$

In that same period, specifically in 1987, an important function of the subthalamic nucleus was identified in PD; multiple teams of scientists in different parts of the world carried out experimental works, which were initially performed in animal models with Parkinsonism and subsequently in humans affected with the disease. ${ }^{71-73}$

Bergman, Witchman and De Long observations in relation to the response with a lesion in the subthalamic nucleus provides an important weapon for the development of what perhaps is considered one of the greatest discoveries of that time: high-frequency deep brain stimulation. ${ }^{74}$ The year of 1993 is considered a watershed with regard to functional surgery: Alim-Louis Benabid reported the implantation of electrodes in the subthalamic nucleus. ${ }^{75}$ Owing to this, 1987 is considered to be the year deep brain stimulation was born, and 30 years after this valuable contribution, different functional neurosurgery and deep brain stimulation procedures are available, which have evolved along with contemporary technologies, which also progress incessantly.

\section{Conclusion}

Two-hundred years have elapsed since the description of PD, and over this time, various teams of scientists have incessantly worked to be able to identify its etiology, understand its pathophysiology and develop new treatments to improve symptoms or to modify disease progression. The road has been arduous, and although in this document only the most relevant facts have been mentioned, it can be appreciated that discoveries have been accelerating along with technological development and access to information globalization. There's still a long way to go, and it is the responsibility of today's scientists and doctors to continue writing history day after day in order to find the cure, which has eluded us during the past two centuries.

\section{References}

1. Keppel-Hesselink JM. Evolution of concepts and definitions of Parkinson's disease since 1817. J Hist Neurosci. 1996; 5:200-207.

2. Hurwitz B. Urban observation and sentiment in James Parkinson's essay on the shaking palsy (1817). Lit Med. 2014;32:74-104.

3. Parkinson J. Definition, history, illustrative cases. En: An essay on shaking palsy. Londres: Whittingham and Rowland; 1817.

4. León R. Historia de la levodopa; un tratamiento anunciado desde la antigüedad. AFT. 2007;5:205-207.
5. García P. Prehistoria de la enfermedad de Parkinson. Neurologia. 2004; 19:735-737.

6. Jonker MA. Estimation of life expectancy in the Middle Ages. J R Statist Soc A. 2003;166:105-117.

7. Rosler R, Young P. La lección de anatomía del doctor Nicolaes Tulp: el comienzo de una utopía médica. Rev Med Chile. 2011;139:535-541.

8. Charcot JM. Lecture VII: On slow compression of the spinal cord. En: Lectures on the diseases of the nervous system. Londres: New Sydenham Society; 1881.

9. Charcot JM. De la paralysie agitante. En: Oeuvres complètes. Leçons sur les maladies du système nerveux. Tomo I. París: Bureaux du Progrès Médical; 1892. pp. 155-188.

10. Lewy FH. Zur pathologischen Anatomie der Paralysis agitans. Deutsche Zeitschrift für Nervenheilkunde. 1913;50:50-55.

11. Trétiakoff $\mathrm{K}$. Contribution à l'étude de l'anatomie pathologique du locus niger de Soemmering avec quelques déductions relatives à la pathogénie des troubles du tonus musculaire et de la maladie de Parkinson. Francia: Universidad de París; 1919.

12. Bethlem J, Den-Hartog-Jager WA. The incidence and characteristics of Lewy bodies in idiopathic paralysis agitans (Parkinson's disease). J Neurol Neurosurg Psychiatry. 1960;23:74-80.

13. Braak H, Del-Tredici K, Rüb U, De-Vos RA, Jansen-Steur EN, Braak E. Staging of brain pathology related to sporadic Parkinson's disease. Neurobiol Aging. 2003;24:197-211.

14. Langston JW, Ballard P, Tetrud JW, Irwin I. Chronic parkinsonism in humans due to a product of meperidine-analog synthesis. Science. 1983; 219:979-980.

15. Angot E, Steiner JA, Hansen C, Li JY, Brundin P. Are synucleinopathies prion-like disorders? Lancet Neurol. 2010;9:1128-1138.

16. Hasegawa M, Nonaka T, Masuda-Suzukake M. Prion-like mechanisms and potential therapeutic targets in neurodegenerative disorders. Pharmacol Ther. 2017;172:22-33.

17. Polymeropoulos MH, Lavedan C, Leroy E, Ide SE, Dutra A, Pike B, et al. Mutation in the alpha-synuclein gene identified in families with Parkinson's disease. Science. 1997;276:2045-2047.

18. Nussbaum RL, Polymeropoulos MH. Genetics of Parkinson's disease. Hum Mol Genet. 1997;6:1687-1691.

19. Jones AC, Yamamura Y, Almasy L, Bohlega S, Elibol B, Hubble J, et al. Autosomal recessive juvenile parkinsonism maps to 6q25.2-q27 in four ethnic groups: detailed genetic mapping of the linked region. Am J Hum Genet. 1998;63:80-87

20. Bonifati V, Rizzu P, Van-Baren MJ, Schaap O, Breedveld GJ, Krieger E, et al. Mutations in the DJ-1 gene associated with autosomal recessive early-onset parkinsonism. Science. 2003;299:256-259.

21. Hatano Y, Li Y, Sato K, Asakawa S, Yamamura Y, Tomiyama $\mathrm{H}$, et al. Novel PINK1 mutations in early-onset parkinsonism. Ann Neurol. 2004;56:424-427.

22. Zimprich A, Biskup S, Leitner $\mathrm{P}$, Lichtner $\mathrm{P}$, Farrer $\mathrm{M}$, Lincoln $\mathrm{S}$, et al. Mutations in LRRK2 cause autosomal-dominant parkinsonism with pleomorphic pathology. Neuron. 2004:44:601-607.

23. Katzenschlager R, Evans A, Manson A, Patsalos PN, Ratnaraj N, Watt H, et al. Mucuna pruriens in Parkinson's disease: a double blind clinical and pharmacological study. J Neurol Neurosurg Psychiatry. 2004; 75:1672-1677.

24. Guebila MB, Thiele I. Model-based dietary optimization for late-stage, levodopa-treated, Parkinson's disease patients. NPJ Syst Biol Appl. 2016;2:16013.

25. Nagashima $\mathrm{Y}$, Kondo T, Sakata M, Koh J, Ito H. Effects of soybean ingestion on pharmacokinetics of levodopa and motor symptoms of Parkinson's disease: in relation to the effects of Mucuna pruriens. J Neurol Sci. 2016;361:229-234

26. Ordenstein L. Étiologie, pronostic, thérapeutique. En: Sur la paralysie agitante et la sclérose plaque généralisée. Francia: A Delahaye, Libraire-Éditeur; 1868.

27. Charcot JM. Leçon 5. En: Oeuvres complètes de J.M. Leçons sur les maladies du système nerveux. Tomo I. Bureaux du Progrès Médical; París: 1892.

28. Gowers WR. Paralysis agitans. En: A system of medicine. Londres: Macmillan; 1899.

29. Gowers WR. Paralysis agitans. En: A manual of diseases of the nervous system. Londres: J. \& A.; 1888.

30. Fahn S. The history of dopamine and levodopa in the treatment of Parkinson's disease. Mov Disord. 2008;23:497-508.

31. Carlsson A, Waldeck B. A fluorimetric method for the determination of dopamine (3Пhydroxytyramine). Acta Physiol Scand. 1958;44:293-298.

32. Price KS, Farley IJ, Hornykiewicz O. Neurochemistry of Parkinson's disease: relation between striatal and limbic dopamine. Adv Biochem Psychopharmacol. 1978;19:293-300.

33. Lloyd K, Davidson L, Hornykiewicz O. The neurochemistry of Parkinson's disease: effect of L-dopa therapy. J Pharmacol Exp Ther. 1975;195:453-464.

34. Ehringer $\mathrm{H}$, Hornykiewicz, $\mathrm{O}$. Distribution of noradrenaline and dopamine (3-hydroxytyramine) in the human brain and their behavior in diseases of the extrapyramidal system. Parkinsonism Relat Disord. 1960;4:53-57. 
35. Montagu KA. Catechol compounds in rat tissues and in brains of different animals. Nature. 1957;180:244-245.

36. Blaschko H. The specific action of L-dopa decarboxylase. J Physiol. 1939;96:50-51.

37. Holtz P. Dopa decarboxylase. Naturwissenschaften. 1939:27:724-725.

38. Cotzias GC, Van-Woert MH, Schiffer LM. Aromatic amino acids and modification of parkinsonism. N Engl J Med. 1967;276:374-379.

39. Cotzias GC, Papavasiliou PS, Gellene R. Modification of Parkinsonism: chronic treatment with L-dopa. N Engl J Med. 1969;280:337-345.

40. Fahn S. Parkinson disease the effect of levodopa and the ELLDOPA trial. Earlier vs later L-dopa. Arch Neurol. 1999;56:529-535.

41. Doshay LJ, Constable K. Newer drugs in the treatment of parkinsonism. Neurology. 2001;57:4-10.

42. Corbin KB. Trihexyphenidyl; evaluation of the new agent in the treatment of Parkinsonism. J Am Med Assoc. 1949;141:377-382.

43. Bertol E, Fineschi V, Karch SB, Mari F, Riezzo I. Nymphaea cults in ancient Egypt and the New World: a lesson in empirical pharmacology. J R Soc Med. 2004;97:84-85.

44. Taba P, Lees A, Stern G. Erich Harnack (1852-1915) and short history of apomorphine. Eur Neurol. 2013;69:321-324.

45. Matthiessen A. Researches into the chemical constitution of the opium bases. Part I.- On the action of hydrochloric acid on morphia. Proc R Soc Lond. 1868;17:455-460.

46. Matthiessen A, Wright C. Apomorphia, a new base derived from morphine. Pharm J Tr. 1869;11-12.

47. Djamshidian A, Poewe W. Apomorphine and levodopa in Parkinson's disease: two revolutionary drugs from the 1950's. Parkinsonism Relat Disord. 2016;33:S9-S12

48. Schwab RS, Amador LV, Lettvin JY. Apomorphine in Parkinson's disease. Trans Am Neurol Assoc. 1951;56:251-253.

49. Ernst AM. Relation between the action of dopamine and apomorphine and their O-methylated derivatives upon the CNS. Psychopharmacologia. 1965:7:391-399.

50. Cotzias GC, Düby S, Ginos JZ, Steck A, Papavasiliou PS. Dopamine analogues for studies of parkinsonism. N Engl J Med. 1970;283:1289.

51. Cotzias GC, Papavasiliou PS, Tolosa ES, Mendez JS, Bell-Midura M. Treatment of Parkinson's disease with aporphines: Possible role of growth hormone. N Engl J Med. 1976;294:567-572.

52. Stibe C, Lees A, Stern G. Subcutaneous infusion of apomorphine and lisuride in the treatment of parkinsonian on-off fluctuations. Lancet. $1987 ; 1: 871$

53. Lees AJ, Haddad S, Shaw KM, Kohout LJ, Stern GM. Bromocriptine in parkinsonism: a long-term study. Arch Neurol. 1978;35:503-505.

54. Pearce RK, Banerii T, Jenner P, Marsden CD. De novo administration of ropinirole and bromocriptine induced less dyskinesia than Lndopa in the MPTP-treated marmoset. Mov Disord. 1998;13:234-241.

55. Rascol O, Pathak A, Bagheri H, Montastruc JL. Dopaminagonists and fibrotic valvular heart disease: further considerations. Mov Disord. 2004;19:1524-1425.

56. Hobson DE, Pourcher E, Martin WR. Ropinirole and pramipexole, the new agonists. Can J Neurol Sci. 1999;26:S27-S33.
57. Metman LV, Gillespie M, Farmer C, Bibbiani F, Konitsiotis S, Morris M, et al. Continuous transdermal dopaminergic stimulation in advanced Parkinson's disease. Clin Neuropharmacol. 2001;24:163-169.

58. Pfeiffer RF. Potential of transdermal drug delivery in Parkinson's disease. Drugs Aging. 2002:19:561-570.

59. Jenner P, Könen-Bergmann, M, Schepers C, Haertter S. Pharmacokinetics of a once-daily extended-release formulation of pramipexole in healthy male volunteers: three studies. Clin Ther. 2009;31:2698-2711.

60. Auffret M, Le-Jeune F, Maurus A, Drapier S, Houvenaghel JF, Robert GH, et al. Apomorphine pump in advanced Parkinson's disease: Effects on motor and nonmotor symptoms with brain metabolism correlations. J Neurol Sci. 2017;372:279-287.

61. Bar Am O, Amit T, Youdim MB. Contrasting neuroprotective and neurotoxic actions of respective metabolites of anti-Parkinson drugs rasagiline and selegiline. Neurosci Lett. 2004;355:169-172.

62. Schwab RS, England AC, Poskanzer DC, Young RR. Amantadine in the treatment of Parkinson's disease. JAMA. 1969;208:1168-1170.

63. Foerster $\mathrm{O}$, Penfield $\mathrm{W}$. The structural basis of traumatic epilepsy and results of radical operation. Brain 1930; 53:99-119.

64. Meyers RA. Surgical procedure for the alleviation of postencephalitic tremor, with notes on the physiology of premotor fibers. Arch Neurol Psychiatry. 1940;44:455-459.

65. Bucy PC, Case TJ. Tremor, physiologic mechanism and abolition by surgical means. Archi Neurol. 1939;41:721-746.

66. Klemme RM. Surgical treatment of dystonia, paralysis agitans and athetosis. Arch Neurol Psychiatry. 1940;44:926.

67. Spiegel EA, Wycis HT, Marks M, Lee AJ. Stereotaxic apparatus for operations on the human brain. Science. 1947;106:349-350.

68. Cooper IS. Ligation of the anterior choroidal artery for involuntary movements; parkinsonism. Psychiatr Q. 1953;27:317-319.

69. Hassler R. The influence of stimulations and coagulations in the human thalamus on the tremor at rest and its physiologic mechanism. Proc Second Intl Congr Neuropath. 1:637-642.

70. Laitinen LV, Bergenheim AT, Hariz MI. Leksell's posteroventral pallidotomy in the treatment of Parkinson's disease. J Neurosurg. 1992;76:53-61.

71. Smith $Y$, Parent A. Neurons of the subthalamic nucleus in primates display glutamate but not GABA immunoreactivity. Brain Res. 1988;453:353-356.

72. Rodríguez-Oroz MC, Rodríguez M, Guridi J, Mewes K, Chockkman V, Vitek J, et al. The subthalamic nucleus in Parkinson's disease: somatotopic organization and physiological characteristics. Brain. 2001;124:1777-1790.

73. Aziz TZ, Peggs D, Sambrook MA, Crossman AR. Lesion of the subthalamic nucleus for the alleviation of 1-methyl-4-phenyl-1,2,3,6-tetrahydropyridine (MPTP)-induced parkinsonism in the primate. Mov Disord. 1991;6:288-289.

74. Bergman H, Wichmann T, DeLong MR. Reversal of experimental parkinsonism by lesions of the subthalamic nucleus. Science. 1990;249: 1436-1438.

75. Pollak P, Benabid AL, Gross C, Gao DM, Laurent A, Benazzouz A, et al. Effects of the stimulation of the subthalamic nucleus in Parkinson disease. Rev Neurol (Paris). 1993;149:175-176. 